\title{
APPLICATION OF HYDROCALC PROGRAM TO CHOOSE THE OPTIMUM DRIP IRRIGATION SYSTEM DESIGN
}

\section{Waleed M. B. Darwish ${ }^{1 \& *}$, Mohamed A. El-Howeity ${ }^{2}$ and Mohamed S. Elbelkemy ${ }^{3}$}

${ }^{1}$ Assoc. Prof., Ag. Eng., Environ. Studies and Res. Inst., U. of Sadat City, Menoufia, Egypt.

2 Prof. of Soil. Micro., Environ. Studies and Research Inst., U. of Sadat City, Menoufia, Egypt.

3 Grad. Stud. at Environ. Studies and Res. Inst., U. of Sadat City, Menoufia, Egypt.

* E-mail: w_basyone@yahoo.com

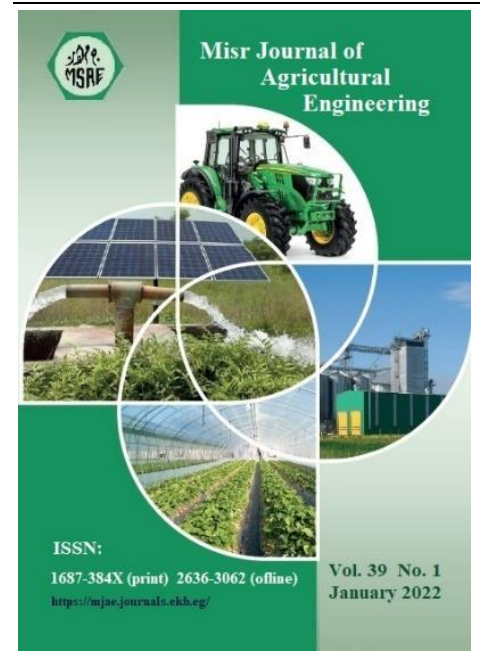

(C) Misr J. Ag. Eng. (MJAE)

\section{Keywords:}

Drip irrigation; HydroCalc program; Optimum design.

\begin{abstract}
Recently the use of irrigation systems design programs is considered one of the most important programs because of its many benefits represented in obtaining the optimal design specifications for different irrigation systems, which leads to maximize both water application efficiency and water use efficiency (WUE) along the irrigation network, especially drip irrigation, while the random design of Irrigation systems affect the regularity and efficiency of water distribution, which negatively affects the production of different crops. Hence, the main objective of this research was to apply the HydroCalc program as one of the irrigation system design programs to choose the optimal design of the drip irrigation system for a new farm in the reclamation areas of the European countryside in Giza province. The coordinates of the study area were raised using a GPS device, which extends over an area of $138 \mathrm{ha}$. The HydroCalc program was used to choose the appropriate diameters and lengths of pipes, as well as calculate the pressure losses for the irrigation network to be designed. The engineering drawing program (AutoCAD) was used to divide the arable areas into plots and draw the appropriate irrigation network and determine its dimensions that were designed with the HydroCalc. In conclusion, the application of using the HydroCalc program helped to choose the appropriate design for the irrigation system.
\end{abstract}

\section{INTRODUCTION}

I rrigation system design is a critical issue of improving irrigation application, efficiency, and economic return in the manufacturing process (Pannunzio et al., 2004). Drip irrigation is among the most efficient and productive method of water and nutrient application to agricultural crops. The water conveyance systems, as well as its emitter devices and the overall system control, must be extremely exact. They require adequate planning and administration. Some scientists are aiming to improve drip irrigation system components including emitters, valves, and control devices. Another group of researchers develops computer programmes to perform drip irrigation system hydraulic calculations. Hydrocalc 
(Netaphim), AquaFlow 3.0 Design (Toro), Norveco, and others are examples of such products. They provide drip irrigation system hydraulic calculations. (Narayanan, et al., 2002) developed a computer program for hydraulic analyses of drip irrigation systems and their optimization. Drip irrigation system modeling is a useful approach to determine the required head for ensuring that irrigation system can distribute water uniformly to the plants easily. This irrigation system modeling aids farmers in determining the head required to complete the system's operational procedure. One method for identifying flaws in a drip irrigation system is to use modeling. With the model, it's simple to run a simulation to show the current state of the drip irrigation system as a whole. This current state of the system is required to ensure that the systems can run as efficiently as possible. Some of these computer models were used to discover the economically optimum pipe size by calculating pressure drop, flow rate, and distribution uniformity of system pipelines network (e.g.manifold, submain, and main lines) (Sharaf and Hassan, 2006; Zella et al., 2006; Ghaemi and Tabarzad, 2014). The size and shape of the irrigated area were both taken into account in computer models while designing a sub-unit (Mahrous et al., 2008; and Nina et al., 2012). (Baiamonte, 2018) Irrilab, a software tool based on explicit relationships, is useful for optimizing the design of rectangular micro-irrigation units in uniform slopes. The older EPANET programme (Rossman, 2000), which has been widely utilized as the computational engine for most water distribution system models, is also promising. One of the most essential elements in evaluating the efficiency of drip irrigation system design is water distribution uniformity. Philipova, et al., (2012) created a tool for designing drip irrigation systems which was done in MATLAB's Graphical User Interface (GUI). Crop water requirements and hydraulic calculations are the two primary components of the programme. It facilitates the selection of soil, crop, climate data, and emitter properties. Tables, edit texts, radio buttons, pull down menus, and push buttons are just a few of the interactive features available in GUIMATLAB, all of which may be simply integrated and written to do the necessary computations. There are other software programmes that can be used for drip irrigation design, according to Sharu and Razak (2020). These include for example hydrauliCAD, AFT Fathom, InfoWorks, WaterCAD, WaterGEMS, AquaFlow, DIDAS, DOMIS, HydroCalc, IRRICAD, IrriPro, IrriExpress, and IrriLab. These software tools can be used to model pressurized irrigation systems. However, each piece of software has its own set of benefits. Software selection does not always result in a single piece of software; it is dependent on the needs of the study to be conducted. They also favored EPANET software because of its ease of use and the fact that it is open source and free to download. The main objective of this research was to employ hydrocalc program to choose the appropriate drip irrigation system design.

\section{MATERIAL AND METHODS}

\section{General description of the studied area:}

The studied area (138 ha) which has elevations ranged gradually between $97 \mathrm{~m}$ and $118 \mathrm{~m}$ above sea level (A.S.L) with different slope degrees towards north direction. The higher elevation value that recorded from 111-118m A.S.L about $41 \%$ for the studied area, when the lower elevation value that recorded from 97-103 $\mathrm{m}$ A.S.L about $16 \%$ for the studied area. Moreover, the other elevation value that recorded from 104-110 m A.S.L about $43 \%$ of the 
studied area. By using GPS, figure (1) showed that, the area of drip irrigation allocated for trees was 60 ha, 18 ha for vegetables, and another cultivated area with sprinkler irrigation for crops comprising 6 ha.

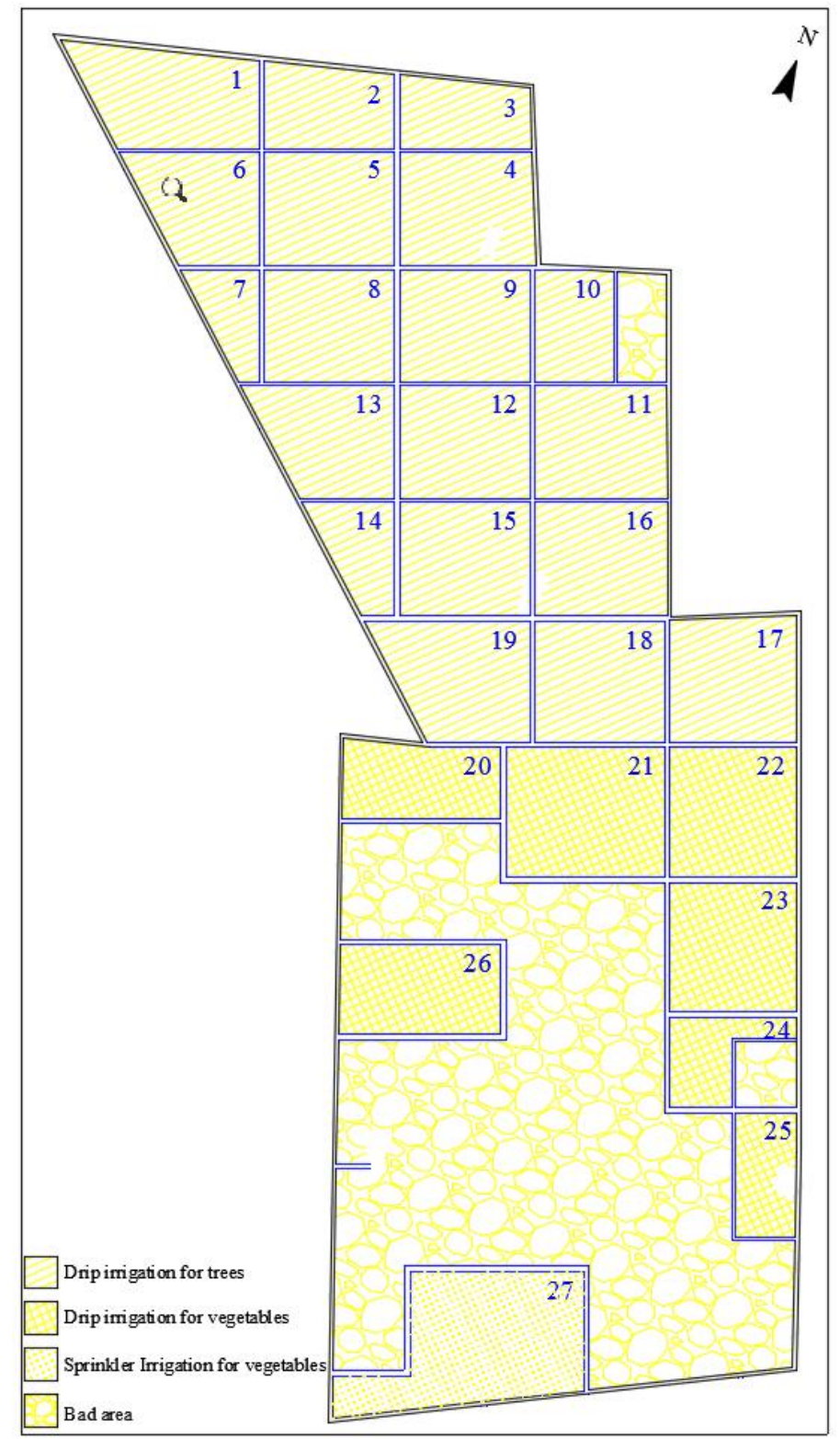

Figure (1): A map showing the excluded places and the places allocated for each irrigation system

\section{HydroCalc irrigation system planning software:}

The HydroCalc irrigation system planning tool is intended to assist the user in determining irrigation system parameters. The user will be able to run the software with any relevant parameters, analyse the output, and adjust the input data to fit it to the right irrigation system setup. Some parameters can be selected from a system list, while others should be supplied by the user based on their own requirements in order to avoid conflicting with the program's limits. An opening main window, five calculating programmes, one language setting window, and a database that the user can improve and update are all included in the software package. HydroCalc has multiple sub-programs, including: 
The emitters programme determines the cumulative pressure loss, average flow rate, water flow velocity, and other parameters in the selected emitter. It can be adjusted to fit the irrigation system's requirements.

- The SubMain application determines the sub-main distributing water pipe's cumulative pressure loss and water flow velocity (single or telescopic). It adapts to the requirements of the irrigation system.

- In the main conducting water pipe, the Main Pipe programme estimates the cumulative pressure loss and the water flow velocity (single or telescopic). It adapts to the requirements of the irrigation system.

- The Shape Wizard programme assists in the transfer of needed system characteristics from the emitters programme to the SubMain programme (Inlet Lateral Flow Rate, Minimum Head Pressure).

- The valves programme calculates the valve friction loss based on the values you provide.

- The Shifts programme determines the watering rate and number of shifts required based on the parameters provided (Gilary, 2008).

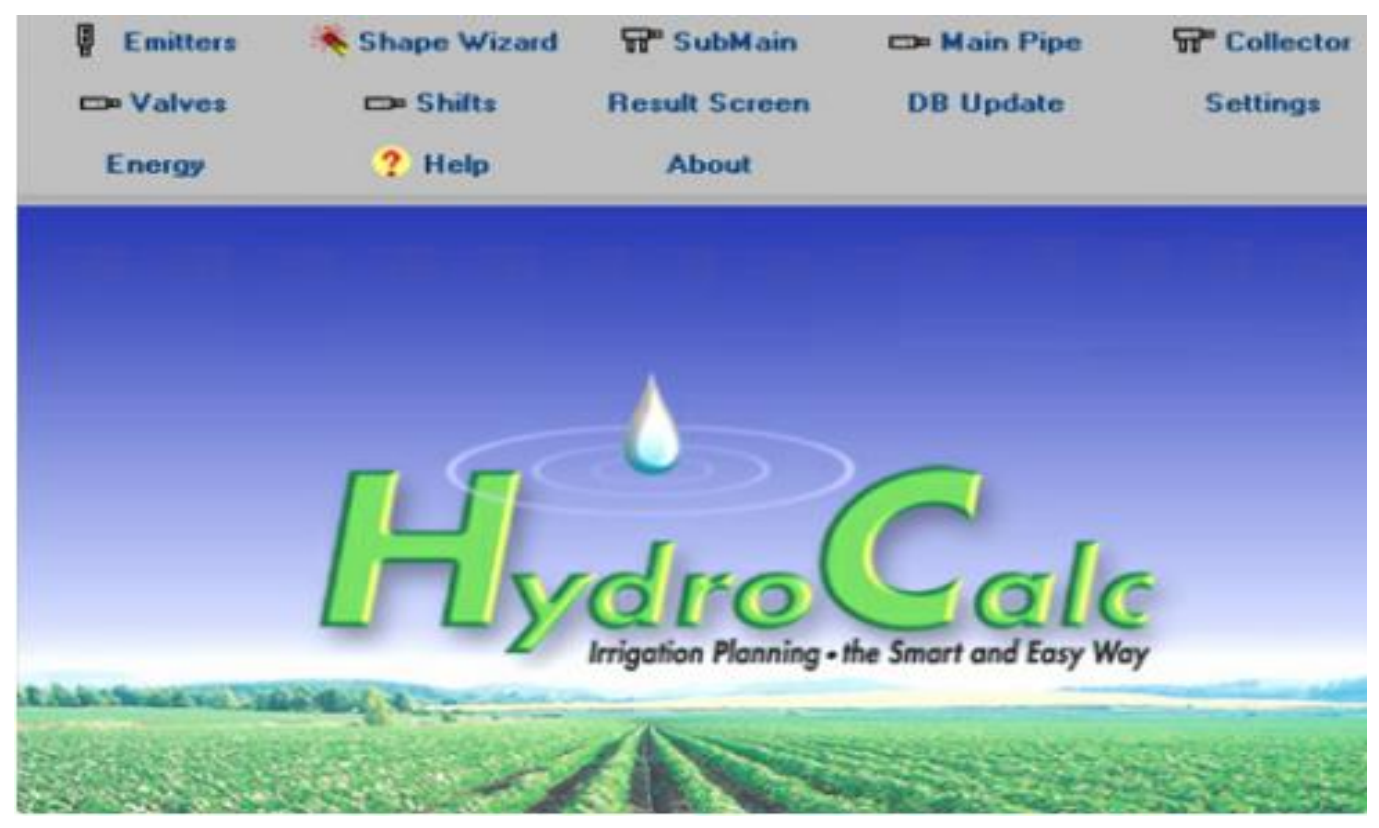

Figure 2. HydroCalc Irrigation Planning

The Emitters programme is the first application included in the HydroCalc package. Drip line, online, sprinklers, and micro-Sprinklers are the four fundamental types of emitters that can be employed. The user can select a certain emitter based on the prior option, which can be pressure compensated or non-pressure compensated. Each emitter has a set of nominal flow rate values at their disposal.

Following the completion of the previously mentioned fields, the computer automatically fills the following fields: "Inside Diameter," "KD," and "Exponent," values that cannot be changed unless a database modification is performed. The next field in which the user must provide a value is the segment length. The end pressure is the actual number used in the pressure 
calculation at the farthest emitter. This variable has some common values: around $10 \mathrm{~m}$ for drippers, around $20 \mathrm{~m}$ for mini-sprinklers, between $20-30 \mathrm{~m}$ for sprinklers, and around $2 \mathrm{~m}$ when flushing. There are two more options that can be filled before the computation prodecure begins, and they can be utilized with their default settings as well. If the user wants to calculate a system that incorporates lateral flushing, the Flushing field might be used. The flushing option will only operate if the "Emitter Line Length" calculation technique is utilized later. The second possibility takes into consideration topography. The default value is $0 \%$. The field of topography is split into two sub-fields: stable slope and variable slope. Normally the slope ratings do not surpass $10 \%$. The slope is not always consistent. The option "Changing" allows the user to select the altitude of up to 10 locations along the line, from end line to sub-main, each consisting of two cells: one for distance and the other for height. The distance from the line's end to the point of altitude change is loaded using the line of distances. There's a chance that these distances aren't equal. Each cell's value is the net distance from the line's end point. Each cell's length value is always greater than the previous cell's length value. The heights line is used to enter the elevations of points whose distance from the line's end is specified above them. The values could be elevation readings from a map or relative height to the end of the line's zero level. Positive numbers indicate that the point is elevated above the line's end, while negative values indicate that the point is elevated below the line's end elevation (Gilary, 2008).

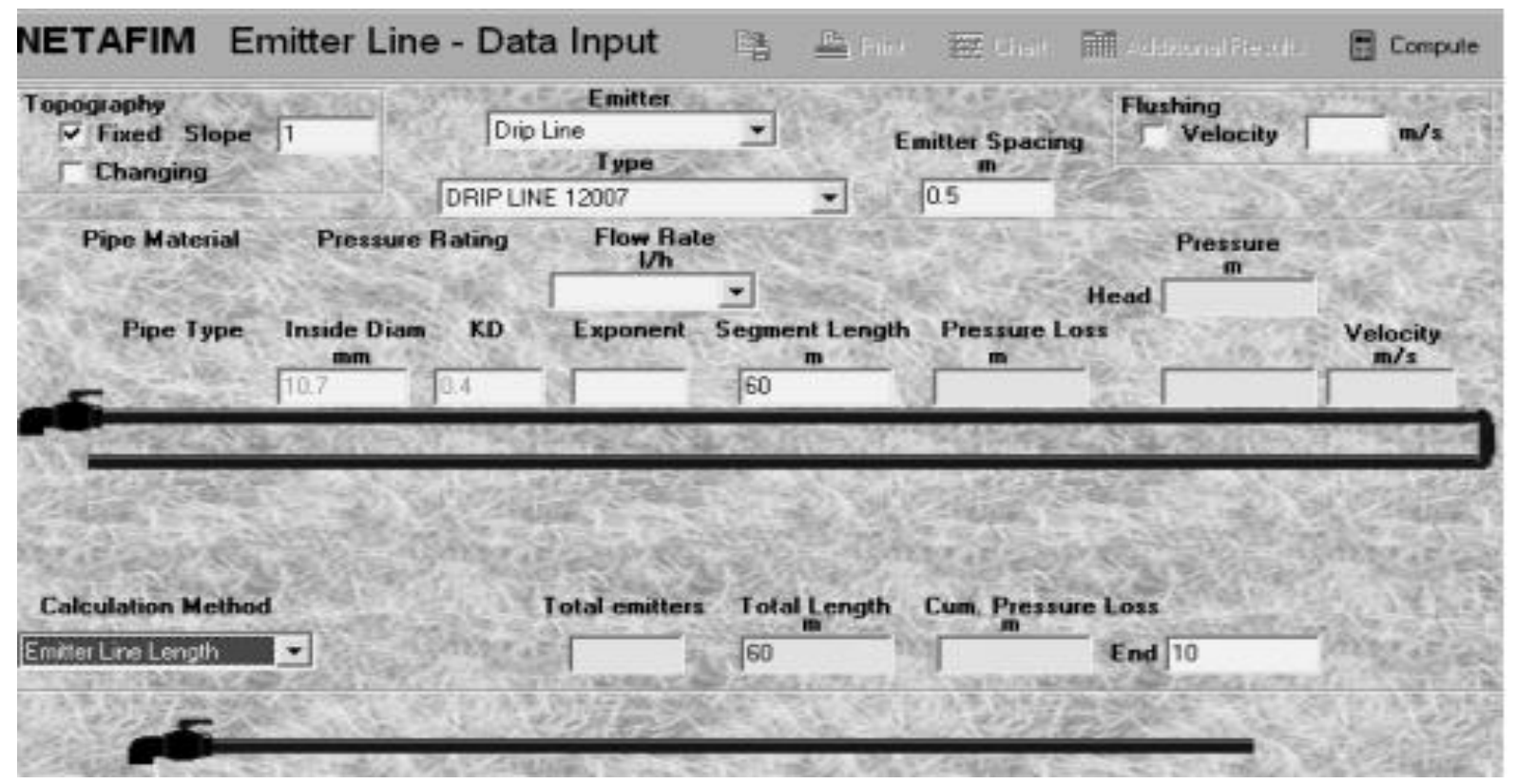

Figure 3. HydroCalc working sheet before computation procedure

For the Emitters subprogram, HydroCalc employs a total of four calculating techniques, each of which is in accordance with the loaded data. The first technique is "Emitter Line Length," which allows for the computation of the total length specified. The second technique is indicated by "Pressure range," a calculation that will be carried out in such a way that the maximum pressure difference between the maximum and minimum emitter pressures does not exceed the user-defined pressure range. The greatest lateral length under the specified parameters will also be shown in the computation outputs. The third computing method, Flow Rate Variation, which can be used to obtain the desired flow variation and will generate the 
maximum lateral length under these conditions. The most common percentages for this field are 10-15 percent. The final calculating approach is "Emission Uniformity," which is similar to "flow rate variation," and will be used to get the greatest lateral length possible. Emission uniformity units are also expressed in precents, but the most typical value for this field is anything greater than $85 \%$ (Gilary, 2008). Figure (4) showed that the flowchart steps of drip irrigation system design procedure using HydroCalc and AutoCAD program.

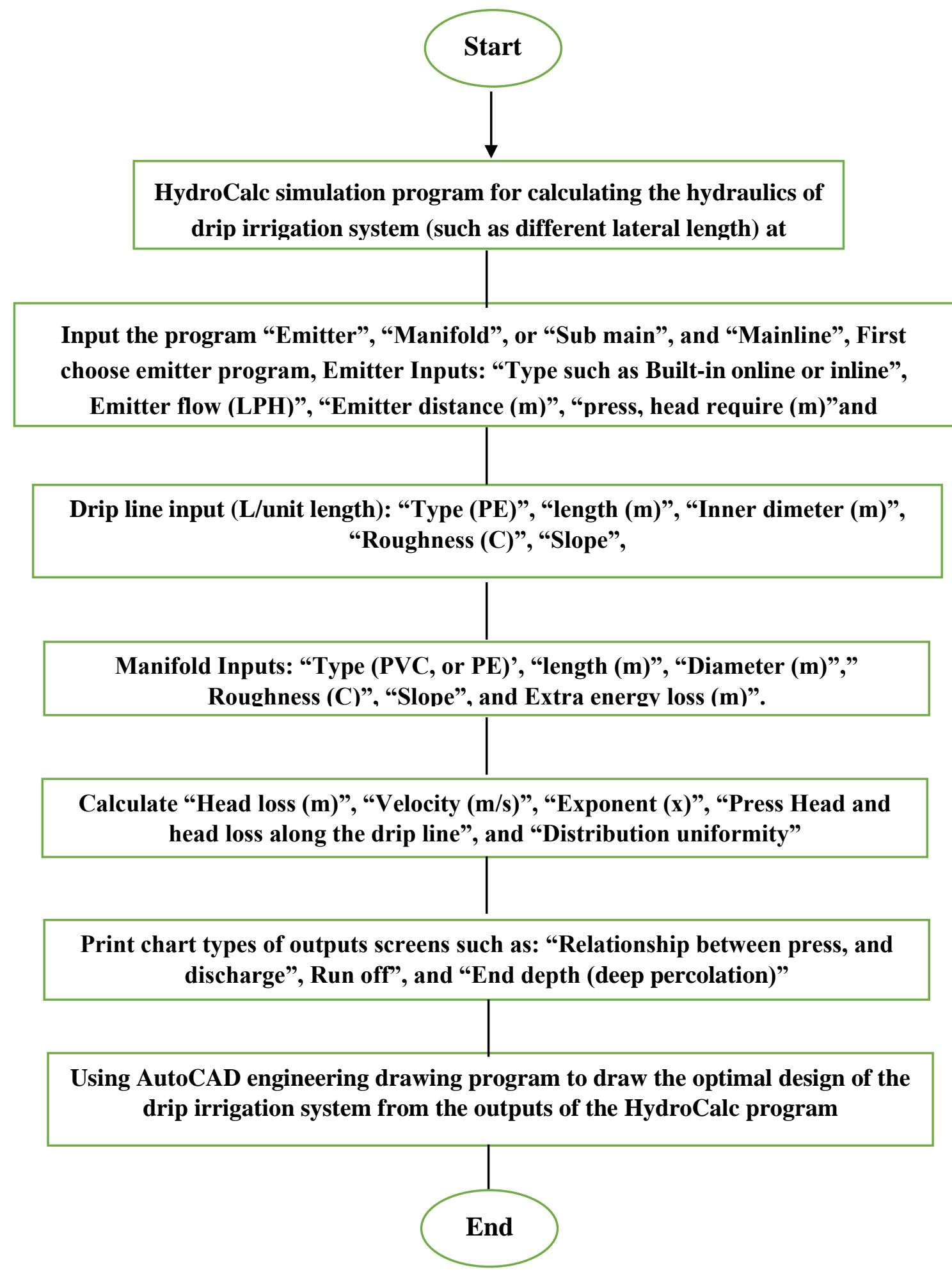

Figure 4: Flowchart of drip irrigation system design procedure using HydroCalc and AutoCAD program 


\section{RESULTS AND DISCUSSION}

\section{Design of the drip irrigation system for trees:}

The appropriate specifications for many trees which have been determined by design

- Distance between lines $5 \mathrm{~m}$.

- 2 lateral is allocated for each line.

- Distances between emitters in the drip line is $50 \mathrm{~cm}$

- Flow rate of emitter is $4 \mathrm{~L} / \mathrm{h}$.

The irrigation network was drawn using the AutoCAD program after dividing the farm into plots and identifying the plots that will be planted with trees with the specifications of the previous irrigation network, where the design for all plots was 175 x $200 \mathrm{~m}$ where, the distance $175 \mathrm{~m}$ is the length of the line of agriculture in the plot and the distance $200 \mathrm{~m}$ is the vertical line of agriculture.

\section{Network design steps}

- The appropriate length of the drip line is determined by one of two ways either refer to the manufacturer's catalog or calculate it on the programs dedicated for this purpose such as HydroCalc.

- determine the initial calculation assuming that no difference of land levels for calculating the flow rate of each drip line and then conduct each submain to determine the diameters of the appropriate pipes to draw the irrigation network on the program properly, and then put the actual land level to know the total pressure loss in the whole network.

- this study was guided by some catalogs to know the appropriate operating pressure of the emitters as well as the appropriate length of the drip line as listed in Table 1.

Table 1: Flow rate (L/h) vs. Pressure (bar)

12010, 16009, 16010, 20010, 23009 - 0.9and1.0mm wall thickness dripper lines

\begin{tabular}{|c|c|c|c|c|c|c|c|c|c|}
\hline \multirow{2}{*}{ Flow rate (L/h)* } & \multicolumn{7}{|c|}{ Pressure (bar) } \\
\cline { 2 - 10 } & $\mathbf{0 . 2}$ & $\mathbf{0 . 4}$ & $\mathbf{0 . 6}$ & $\mathbf{0 . 8}$ & $\mathbf{1 . 0}$ & $\mathbf{1 . 5}$ & $\mathbf{2 . 0}$ & $\mathbf{2 . 5}$ & $\mathbf{3 . 0}$ \\
\hline $\mathbf{0 . 5 5}$ & 0.26 & 0.36 & 0.44 & 0.50 & 0.55 & 0.66 & 0.76 & 0.84 & 0.91 \\
\hline $\mathbf{0 . 8 0}$ & 0.38 & 0.52 & 0.63 & 0.72 & 0.80 & 0.96 & 1.10 & 1.22 & 1.32 \\
\hline $\mathbf{1 . 0 0}$ & 0.48 & 0.66 & 0.79 & 0.90 & 1.00 & 1.21 & 1.38 & 1.53 & 1.66 \\
\hline $\mathbf{1 . 5 0}$ & 0.72 & 0.98 & 1.19 & 1.35 & 1.50 & 1.81 & 2.06 & 2.29 & 2.49 \\
\hline $\mathbf{2 . 0 0}$ & 0.95 & 1.31 & 1.58 & 1.80 & 2.00 & 2.41 & 2.75 & 3.05 & 3.31 \\
\hline $\mathbf{3 . 0 0}$ & 1.43 & 1.97 & 2.37 & 2.71 & 3.00 & 3.61 & 4.13 & 4.57 & 4.97 \\
\hline $\mathbf{4 . 0 0}$ & 1.91 & 2.62 & 3.16 & 3.61 & 4.00 & 4.82 & 5.50 & 6.10 & 6.63 \\
\hline $\mathbf{8 . 0 0}$ & 3.81 & 5.25 & 6.32 & 7.22 & 8.00 & 9.64 & 11.00 & 12.19 & 13.26 \\
\hline
\end{tabular}


Table 2: Max lateral length $(\mathrm{m})$ at different slopes $-10 \%$ flow variation

ARIES HWD - ID 10.2mm - KD0.70 - flow rate $4.00 \mathrm{~L} / \mathrm{h}$ - inlet pressure $1.5 \mathrm{bar}$

\begin{tabular}{|c|c|c|c|c|c|c|c|c|c|}
\hline \multirow{2}{*}{ Slope } & \multicolumn{8}{|c|}{ Distance between drippers (meter) } \\
\cline { 2 - 11 } & $\mathbf{0 . 2 0}$ & $\mathbf{0 . 3 0}$ & $\mathbf{0 . 4 0}$ & $\mathbf{0 . 5 0}$ & $\mathbf{0 . 6 0}$ & $\mathbf{0 . 7 0}$ & $\mathbf{0 . 8 0}$ & $\mathbf{0 . 9 0}$ & $\mathbf{1 . 0 0}$ \\
\hline $2 \%$ & 17 & 23 & 29 & 34 & 38 & 43 & 46 & 50 & 53 \\
\hline $1 \%$ & 17 & 24 & 30 & 36 & 40 & 45 & 50 & 53 & 57 \\
\hline 0 & 18 & 25 & 31 & 37 & 42 & 48 & 52 & 57 & 61 \\
\hline$-1 \%$ & 18 & 25 & 31 & 38 & 43 & 48 & 54 & 59 & 64 \\
\hline$-2 \%$ & 18 & 26 & 32 & 39 & 45 & 50 & 56 & 62 & 67 \\
\hline
\end{tabular}

- The appropriate length of the drip line in the HydroCalc program was calculated as follows:

- The program will be opened and then the button will be pressed to calculate the drip lines. Then the data will be entered into the program, and the selection of the appropriate drip line type will be chosen. The outer diameter of the drip line pipe was $16 \mathrm{~mm}$, and the inner diameter was $13.2 \mathrm{~mm}$. The distance between emitter was $0.5 \mathrm{~m}$. The length of the drip line was $50 \mathrm{~m}$. The pressure losses recorded was $1.25 \mathrm{~m}$. Thus, the length of the line of agriculture $(175 \mathrm{~m})$ can be divided into 4 drip lines of length, with $43.75 \mathrm{~m}$ each $(175 / 4)$ and therefore can be placed in the design of $45 \mathrm{~m}$ (drip line length) and distributed by 2 submain and each submain given to two directions for plot and losses in the pressure of $0.93 \mathrm{~m}$ as shown in Figure 5.

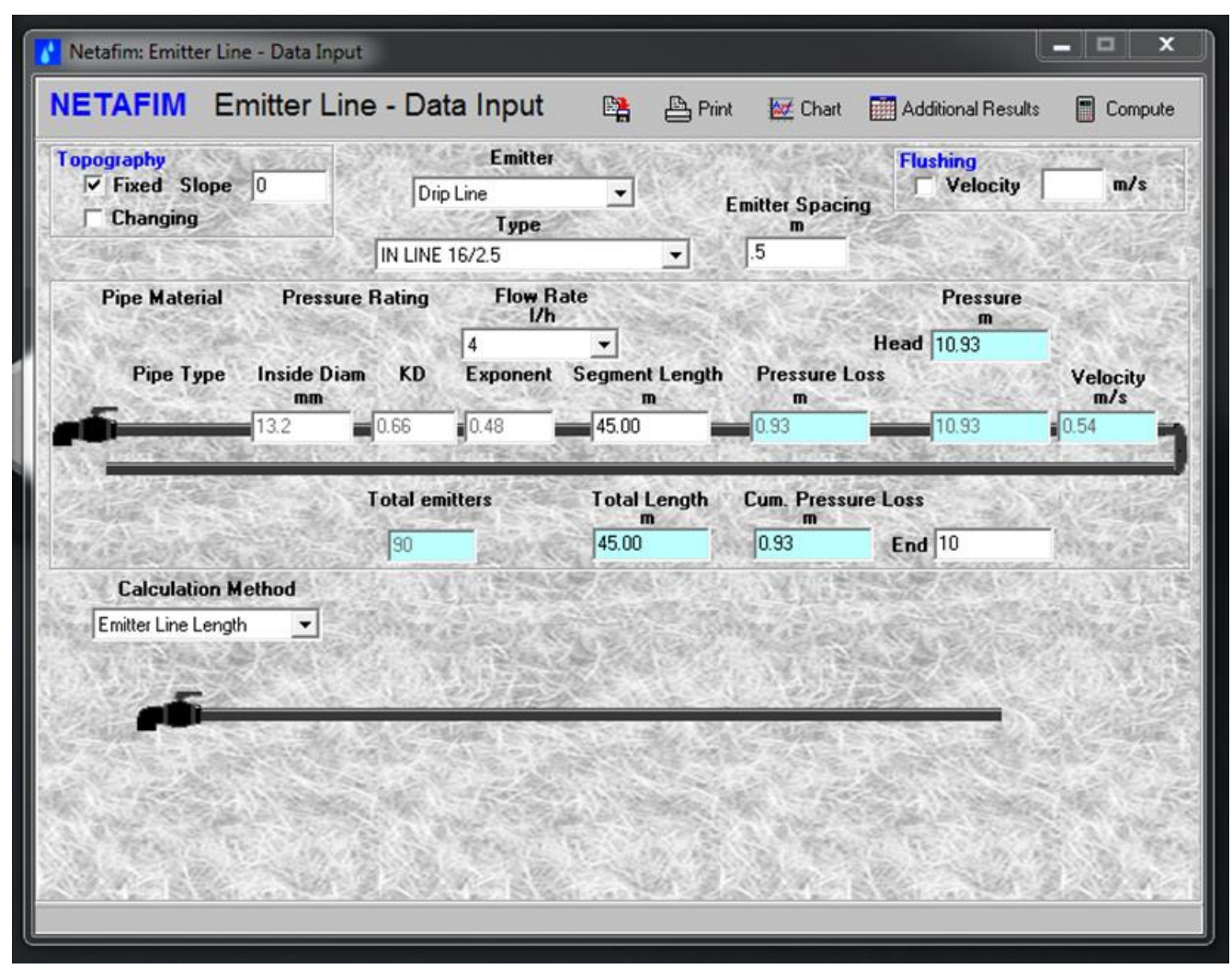

Figure 5: Emitter line - pressure results under slope (0\%)

The results of the program appear in the form of a report as follows in Table 3. 
Table 3: Emitter line result report under slope (0\%)

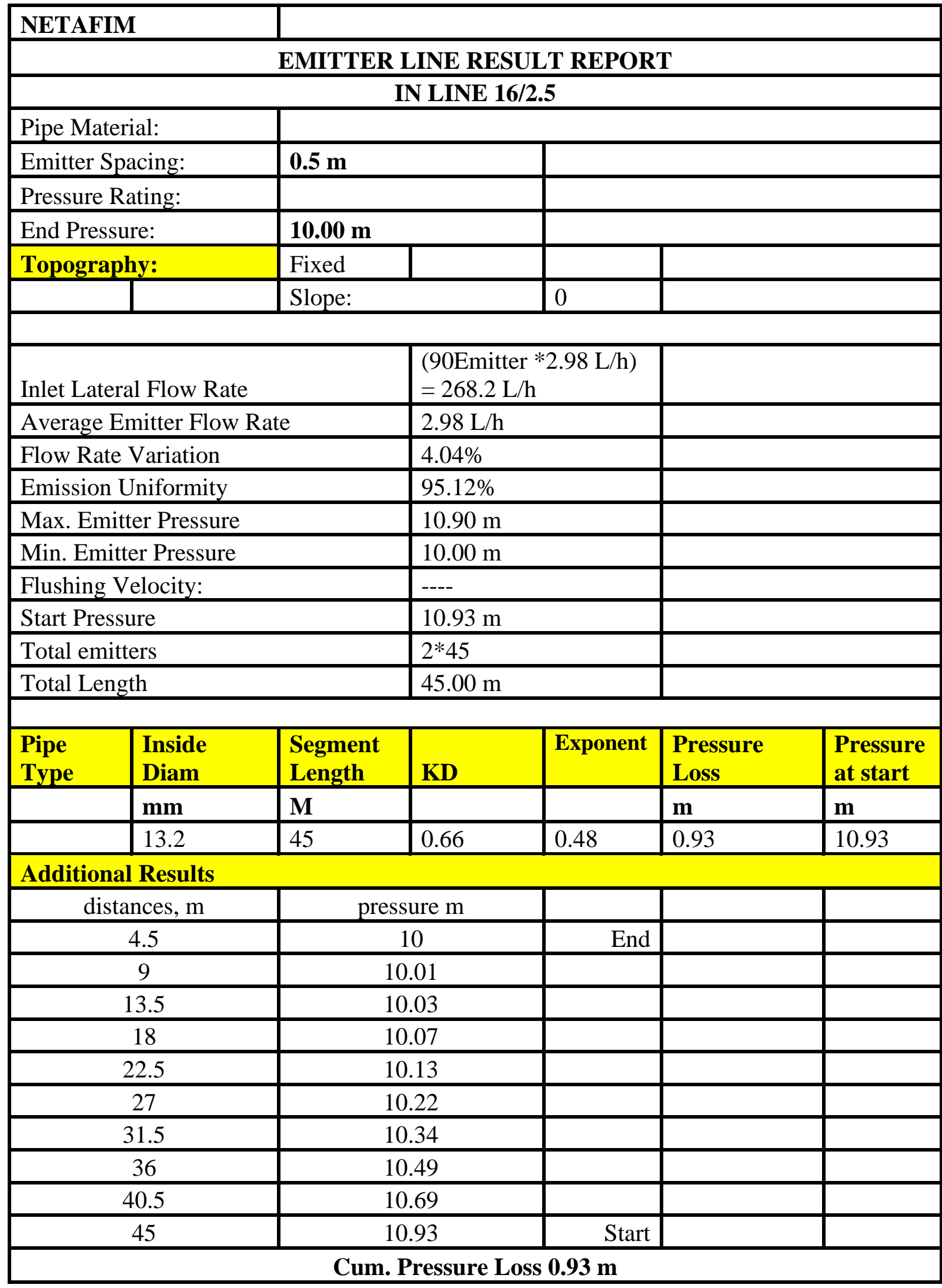

By feeding the program with real land slops of $2 \%$ for the plot, the program results will be as follows as shown in Figure 6 and Table 4. 

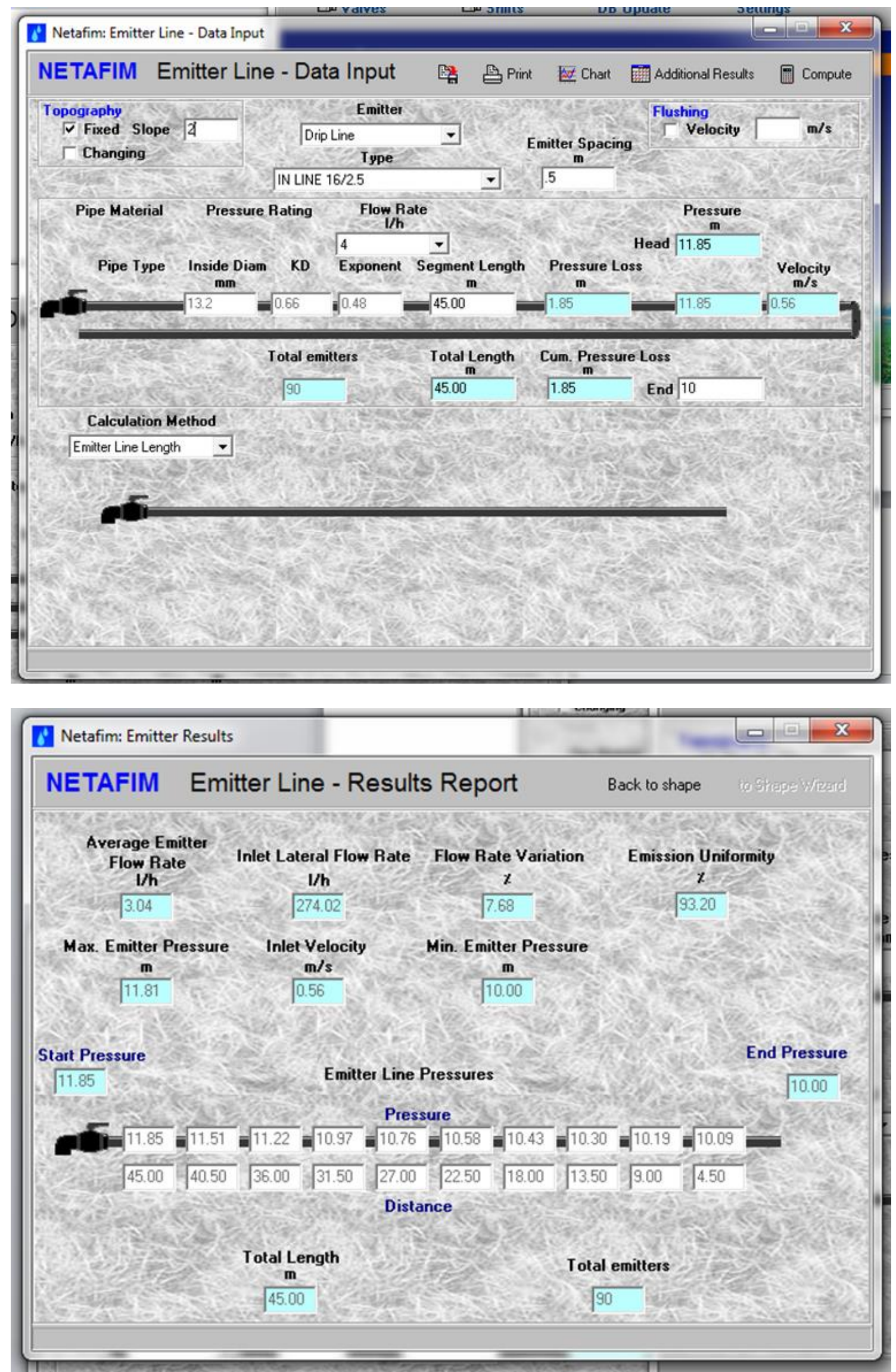

Figure 6: Emitter line - pressure results under slope (2\%) 
Table 4: Emitter line result report under slope (2\%)

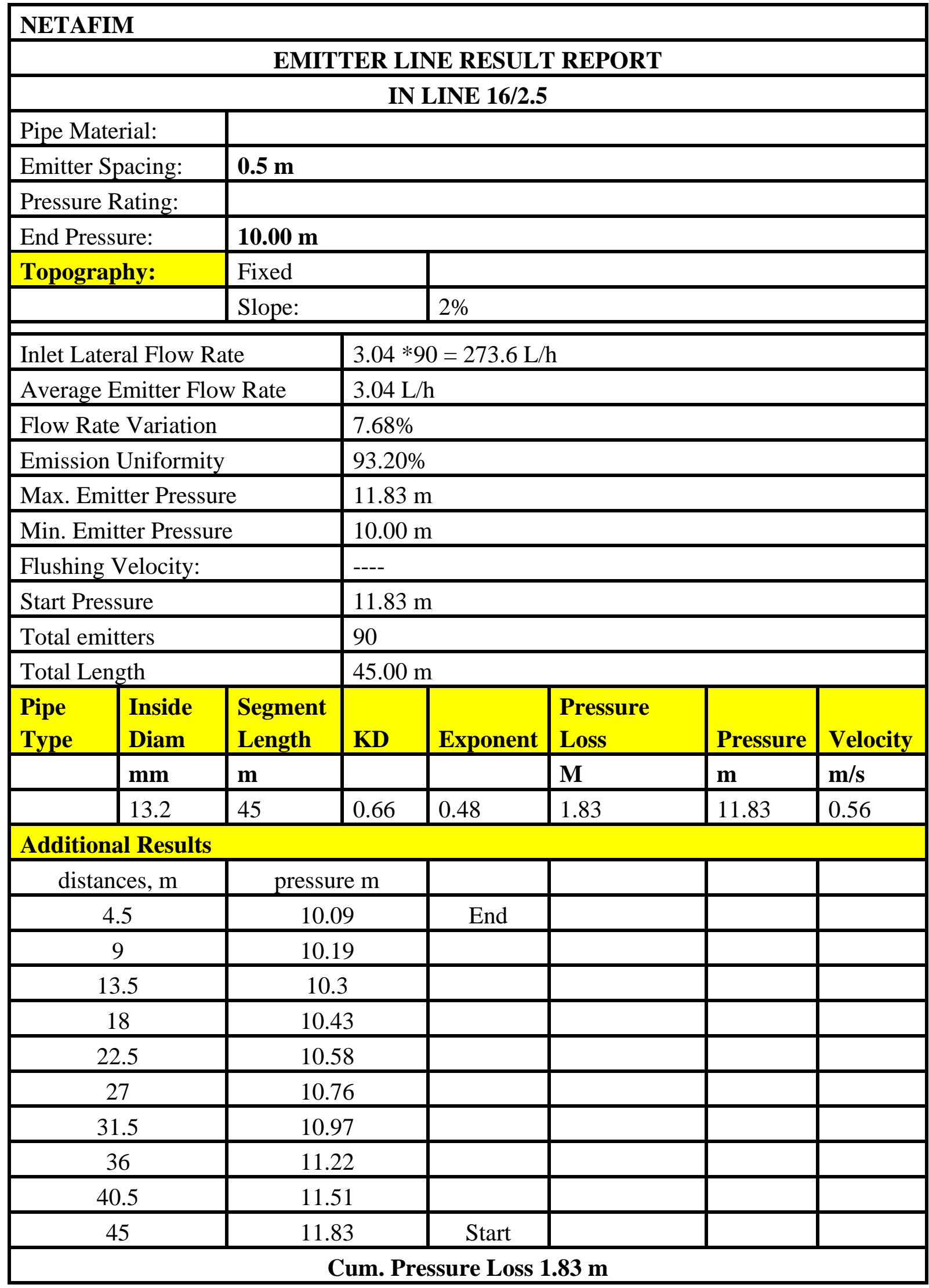

It can be noted that, the total head losses in drip line were $1.83 \mathrm{~m}$ and the head pressure in start drip line was $11.83 \mathrm{~m}$. 


\section{Calculations of sub-main lines of plot under slop $2 \%$}

Figures 7 and Table 5 show the results of calculation the design of the sub-main lines of plot.

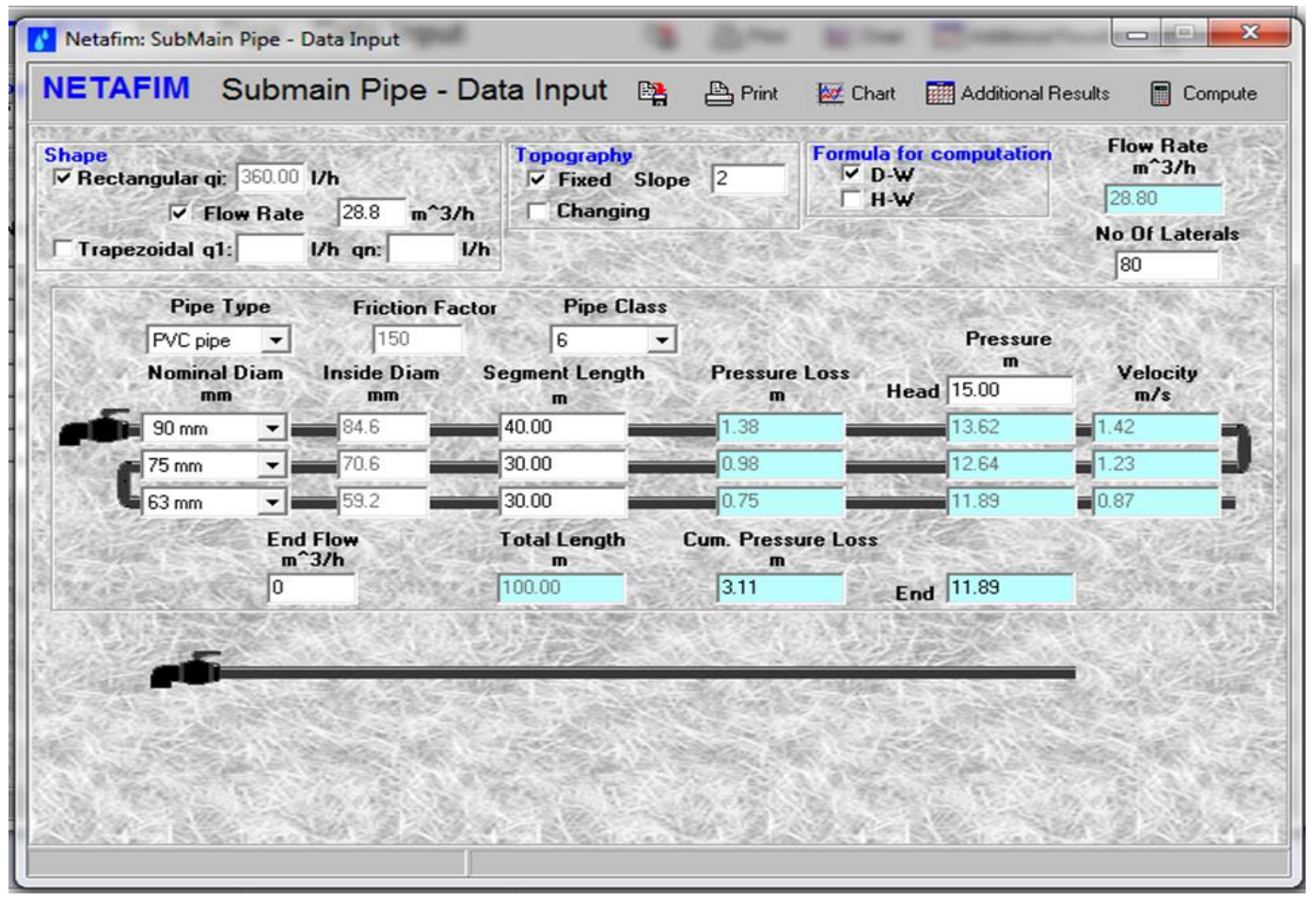

Figure 7: Submain pipe- pressure results

Table 5: Submain water pipe- result report.

\begin{tabular}{|c|c|c|c|c|c|}
\hline \multicolumn{6}{|l|}{ NETAFIM } \\
\hline \multicolumn{6}{|c|}{ SUBMAIN WATER PIPE - RESULT REPORT } \\
\hline \multicolumn{6}{|c|}{ Formula for computation: D-W* } \\
\hline \multicolumn{2}{|l|}{ Pipe Type } & \multicolumn{4}{|l|}{ PVC pipe } \\
\hline \multicolumn{2}{|l|}{ Friction Factor } & \multicolumn{4}{|l|}{150} \\
\hline \multicolumn{2}{|l|}{ Flow Rate } & \multicolumn{4}{|l|}{$28.80 \mathrm{~m}^{3} / \mathrm{h}$} \\
\hline \multicolumn{2}{|l|}{ Pipe Class } & \multicolumn{4}{|l|}{6} \\
\hline \multicolumn{2}{|l|}{ Total Length } & \multicolumn{4}{|l|}{$100.00 \mathrm{~m}$} \\
\hline \multicolumn{2}{|l|}{ Head Pressure } & \multicolumn{4}{|l|}{$15.00 \mathrm{~m}$} \\
\hline \multicolumn{2}{|l|}{ End Pressure } & \multicolumn{4}{|l|}{$11.89 \mathrm{~m}$} \\
\hline \multicolumn{2}{|l|}{ Topography: } & \multicolumn{4}{|l|}{ Fixed } \\
\hline & & \multicolumn{4}{|l|}{ Slope: 2} \\
\hline Nominal Diam & Inside Diam & Segment Length & Pressure Loss & Pressure & Velocity \\
\hline $\mathbf{m m}$ & $\mathbf{m m}$ & $\mathbf{M}$ & $\mathbf{m}$ & $\mathbf{m}$ & $\mathbf{m} / \mathbf{s}$ \\
\hline $90 \mathrm{~mm}$ & 84.6 & 40 & 1.38 & 13.62 & 1.42 \\
\hline $75 \mathrm{~mm}$ & 70.6 & 30 & 0.98 & 12.64 & 1.23 \\
\hline $63 \mathrm{~mm}$ & 59.2 & 30 & 0.75 & 11.89 & 0.87 \\
\hline & & Cum. Pressure I & $3.11 \mathrm{~m}$ & & \\
\hline
\end{tabular}

* Darcy Weisbach Formula: The Darcy formula or the Darcy-Weisbach equation as it tends to be referred to, is now accepted as the most accurate pipe friction loss formula, and although more difficult to calculate and use than other friction loss formula, with the introduction of computers, it has now become the standard equation for hydraulic engineers. 
After launching the program, the following calculations may be achieved:

1- The sub-main line was divided into 3 parts $(40 \mathrm{~m}$ with diameter $90 \mathrm{~mm}, 30 \mathrm{~m}$ with diameter $75 \mathrm{~mm}$ and $30 \mathrm{~m}$ with diameter $63 \mathrm{~mm}$ ).

2- The pressure loss in sub-main line was $3.11 \mathrm{~m}$.

3- The pressure in the start of the submain line $15 \mathrm{~m}$.

\section{Calculations of main lines under $2 \%$ slop.}

The following Figure 8 and Table 6 show the results of determining the design of the main lines.

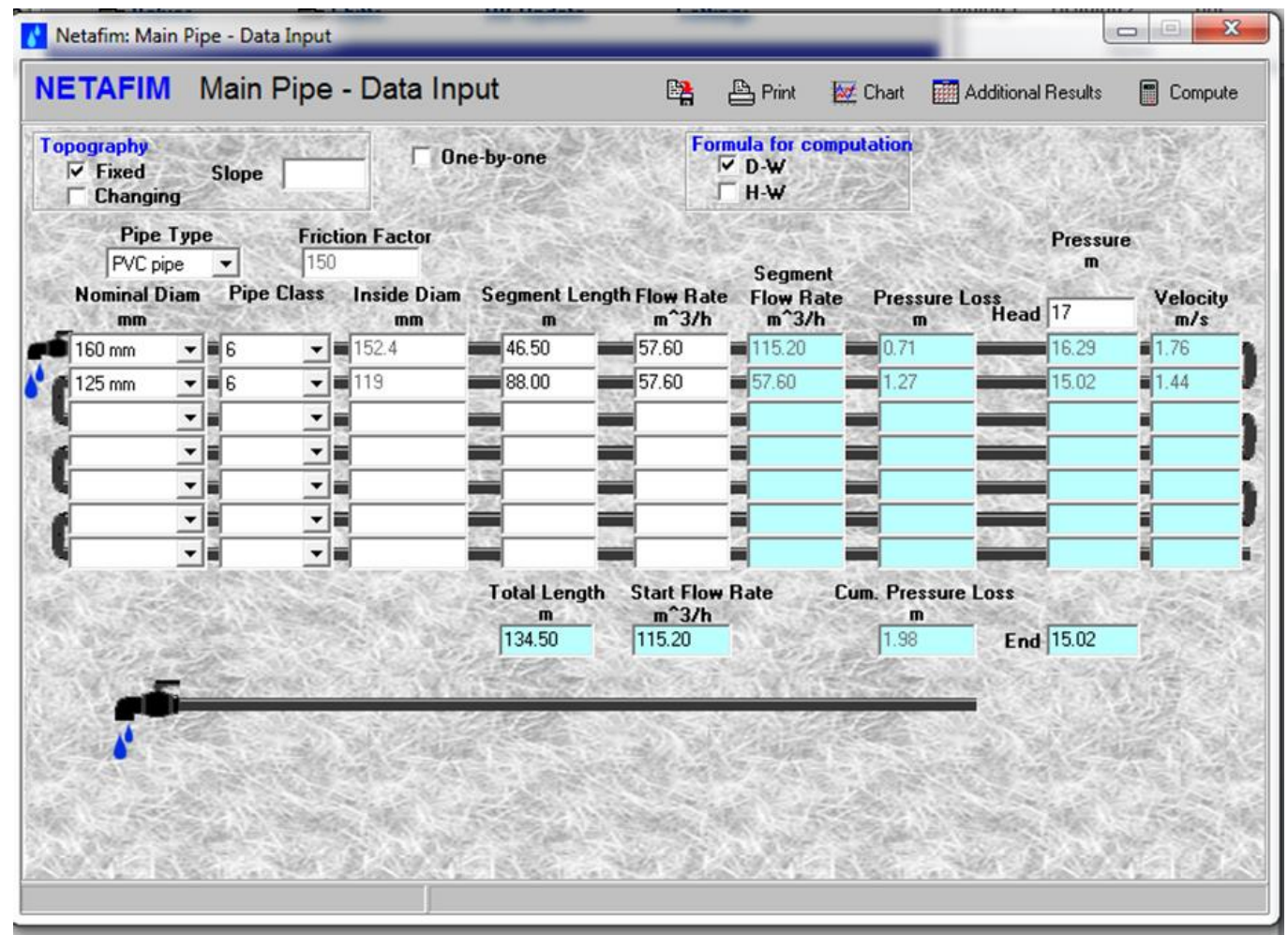

NETAFIM: Main Pipe - Pressure Results, Chart

$+n$

$x$

NETAFIM Main Pipe-Pressure Results 眴 Print

Title PVC pipe, Start Flow Rate $115.20 \mathrm{~m}^{\wedge} 3 / \mathrm{h}$

Change Title

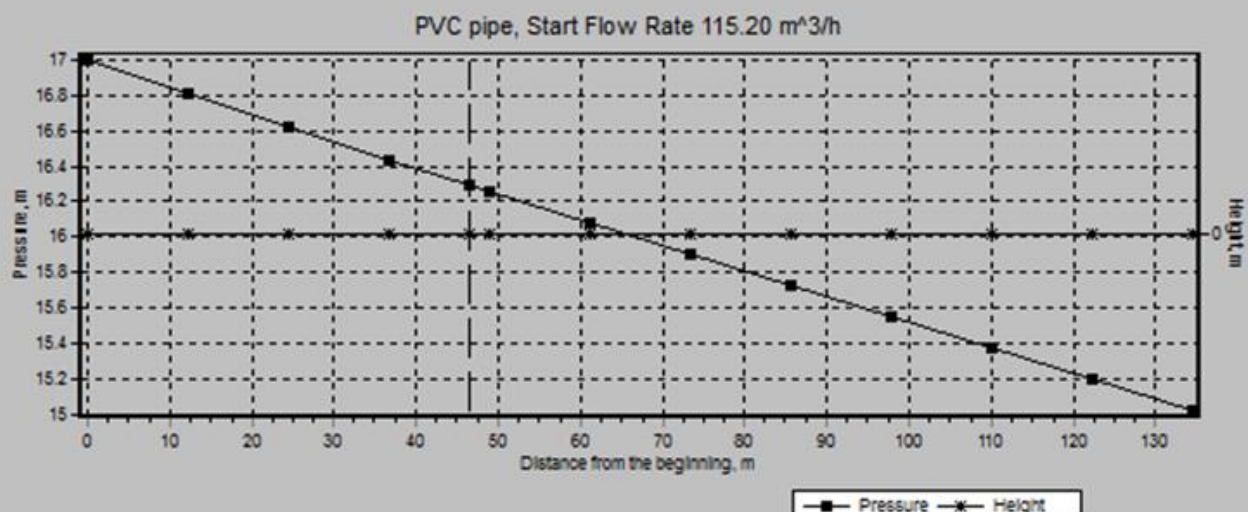

$\rightarrow-$ Pressure $\rightarrow-$ Heignt

Figure 8: Main pipe - pressure results 
Table 6: Main conducting water pipe - result report

\begin{tabular}{|c|c|c|c|c|c|c|c|c|}
\hline \multicolumn{2}{|c|}{ NETAFIM } & & & & & & & \\
\hline \multicolumn{9}{|c|}{ MAIN CONDUCTING WATER PIPE - RESULT REPORT } \\
\hline \multicolumn{9}{|c|}{ Formula for computation: D-W } \\
\hline \multicolumn{2}{|l|}{ Pipe Type } & \multicolumn{7}{|c|}{ PVC pipe } \\
\hline \multicolumn{2}{|c|}{ Friction Factor } & \multicolumn{7}{|l|}{150} \\
\hline \multicolumn{2}{|c|}{ Start Flow Rate } & \multicolumn{7}{|c|}{$115.20 \mathrm{~m}^{3} / \mathrm{h}$} \\
\hline \multicolumn{2}{|c|}{ Total Length } & \multicolumn{7}{|c|}{$134.50 \mathrm{~m}$} \\
\hline \multicolumn{2}{|c|}{ Head Pressure: } & \multicolumn{7}{|l|}{$17 \mathrm{~m}$} \\
\hline \multicolumn{2}{|c|}{ End Pressure: } & \multicolumn{7}{|c|}{$15.02 \mathrm{~m}$} \\
\hline \multirow{2}{*}{\multicolumn{2}{|c|}{ Topography: }} & \multicolumn{7}{|l|}{ Fixed } \\
\hline & & \multicolumn{7}{|l|}{ Slope: } \\
\hline $\begin{array}{l}\text { Nominal } \\
\text { Diam }\end{array}$ & $\begin{array}{l}\text { Pipe } \\
\text { Class } \\
\end{array}$ & $\begin{array}{l}\text { Inside } \\
\text { Diam } \\
\end{array}$ & $\begin{array}{l}\text { Segment } \\
\text { Length } \\
\end{array}$ & $\begin{array}{l}\text { Flow } \\
\text { Rate } \\
\end{array}$ & $\begin{array}{l}\text { Segment } \\
\text { Flow } \\
\text { Rate } \\
\end{array}$ & $\begin{array}{l}\text { Pressure } \\
\text { Loss } \\
\end{array}$ & Pressure & Velocity \\
\hline Mm & & $\mathbf{m m}$ & $\mathbf{m}$ & $\mathbf{m}^{3} / \mathbf{h}$ & $\mathbf{m}^{3} / \mathbf{h}$ & $\mathbf{m}$ & $\mathbf{m}$ & $\mathbf{m} / \mathbf{s}$ \\
\hline $160 \mathrm{~mm}$ & 6 & 152.4 & 46.5 & 57.6 & 115.2 & 0.71 & 16.29 & 1.76 \\
\hline $125 \mathrm{~mm}$ & 6 & 119 & 88 & 57.6 & 57.6 & 1.27 & 15.02 & 1.44 \\
\hline
\end{tabular}

After launching the program, the following calculations can be carried out:

1- The main line was split into two parts $(46.5 \mathrm{~m}$ with diameter $160 \mathrm{~mm}$, and $88 \mathrm{~m}$ with diameter $125 \mathrm{~mm})$.

2- The pressure loss in main line was $1.98 \mathrm{~m}$.

3- The pressure in the start of the main line $17 \mathrm{~m}$.

From the previously mentioned results it can be concluded that: The discharge of plot (11) was $115.2 \mathrm{~m}^{3} / \mathrm{h}$, and the pressure at the start of the main line was $17 \mathrm{~m}$. Figures 9,10 and 11 illustrate the design for drip irrigation system (tree) for the experimental area (plots: 11, 1 and 2).

\section{Design of drip irrigation for vegetables and crops of the experimental area.}

The design is based on the following:

1- cultivation should be in the lines spaced at $55 \mathrm{~cm}$.

2- The distance between emitters was $30 \mathrm{~cm}$.

3- discharge rate of emitter was $2.1 \mathrm{~L} / \mathrm{h}$

4- Discharge rate per ha was $53.5 \mathrm{~m}^{3} / \mathrm{h}$.

The same steps were used in designing drip irrigation for vegetables and crops and the results for the design can be concluded as shown in Figure 12 for experimental area for plot (20). 


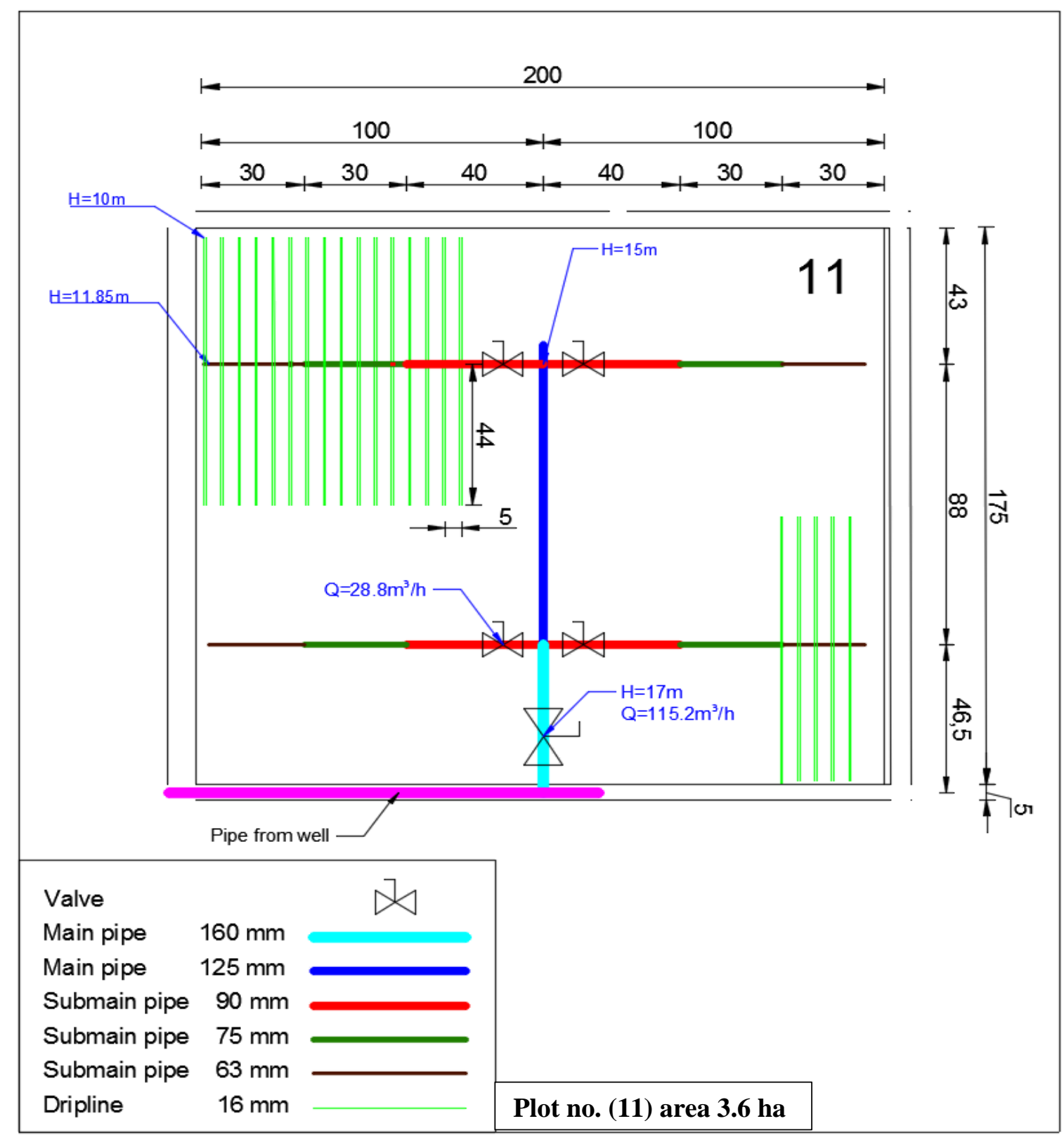

Figure (9): Design of drip irrigation system for tree 


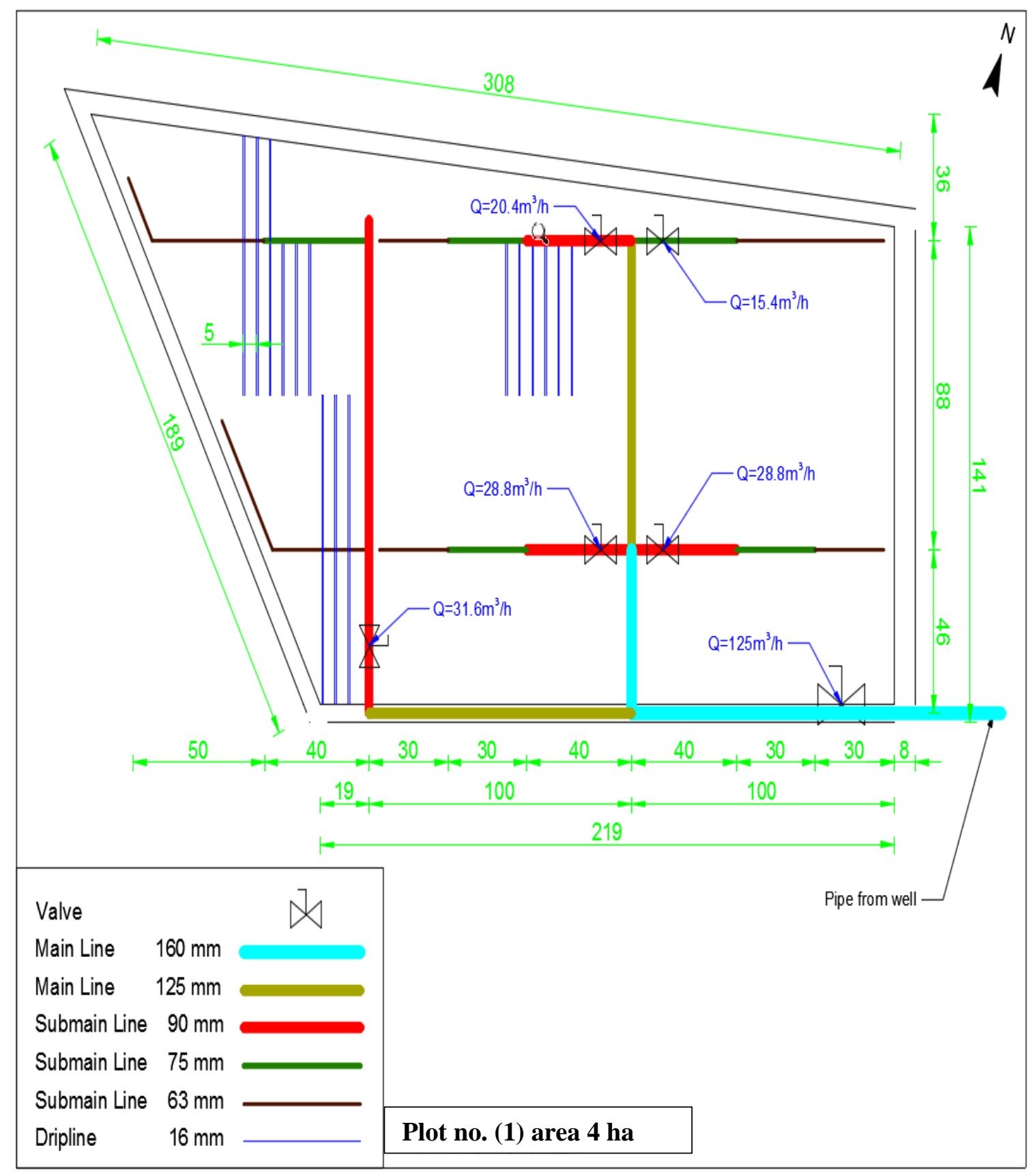

Figure (10): Design drip irrigation system for tree (plot) 


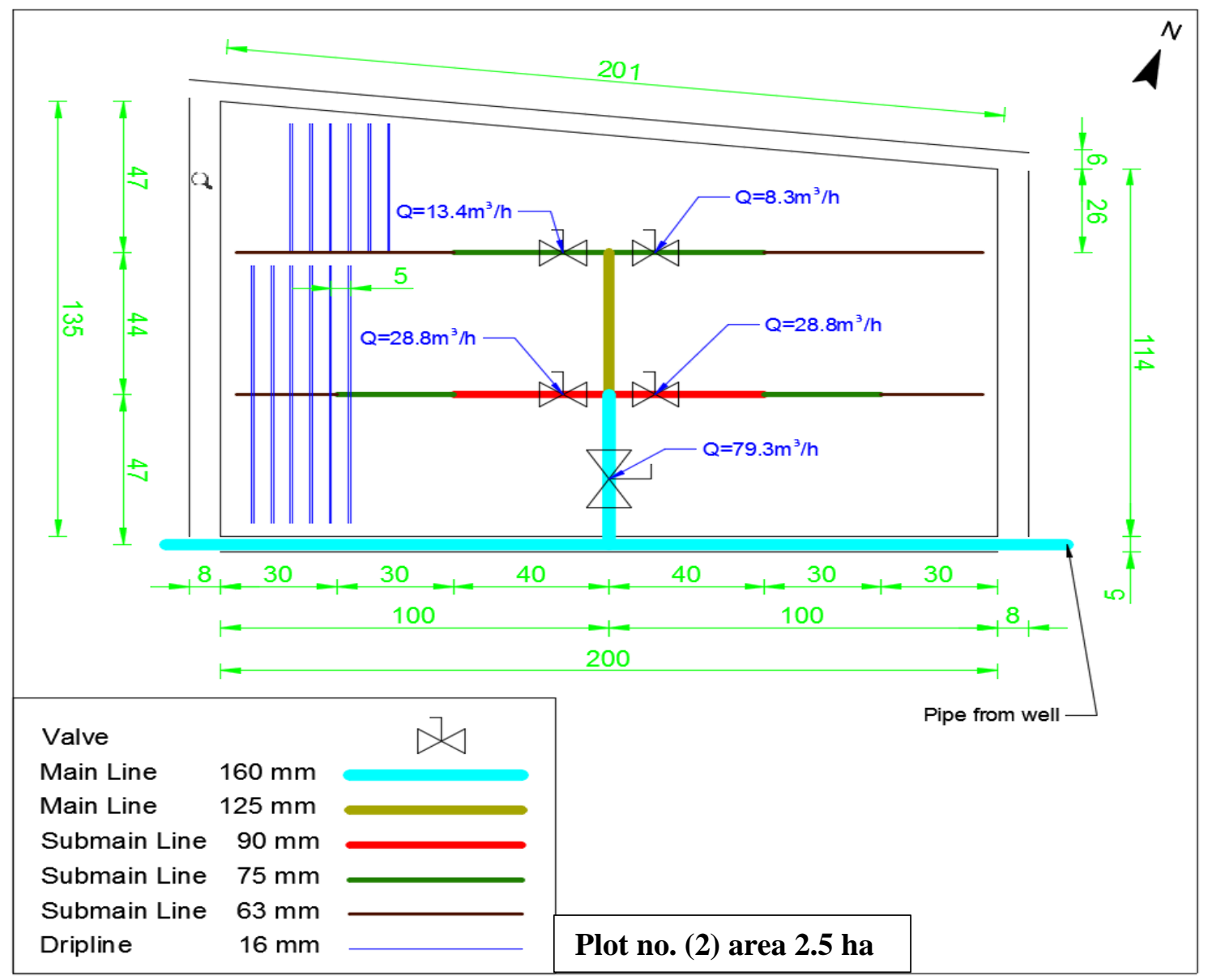

Figure (11): Design drip irrigation system for tree (plot)

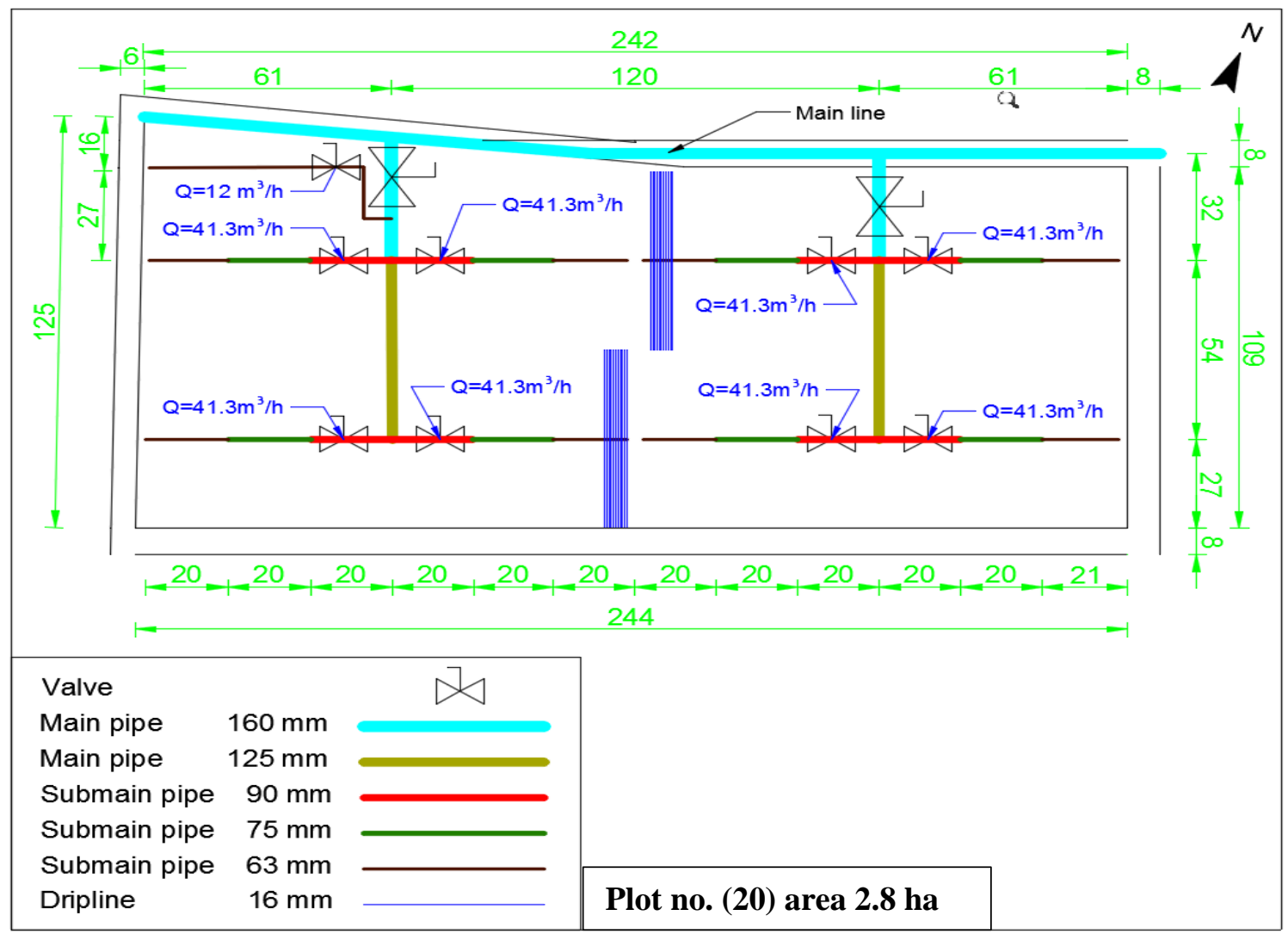

Figure (12): Design of drip irrigation system for vegetables and crops (plot) 


\section{CONCLUSIONS}

In agriculture, drip irrigation is a cost-effective way to apply water. The drip irrigation system allows for a continuous supply of water via drippers at particular positions along the lateral lines, allowing for optimal plant development and soil hydration in the root zone. Because of the effective use of water, enhanced microclimate surrounding the root zone, insect and weed management, and agronomic and economic benefits, a well-designed drip irrigation system can increase crop output and therefore total income.

The results of our research suggest that HydroCalc is a reliable tool for developing drip irrigation systems due to its properties. Also, choosing the economic diameter, reducing the cost of establishing an irrigation network, and reaching the optimal operating pressure. Because of its numerous benefits, this programme should be implemented to aid Egyptian researchers' work and to help students grasp the issues surrounding drip irrigation.

\section{REFERENCES}

Baiamonte, G. (2018). Explicit relationships for optimal designing rectangular microirrigation units on uniform slopes: The IRRILAB software application. Comput. Electron. Agric., 153, 151-168.

Ghaemi, A. A., and Tabarzad. A. (2014). Development of micro irrigation design software (mids) to optimize total project cost and hydraulic parameters. Transactions of Civil Engineering, 38(C1): 297-307.

Gilary, E. (2008). HydroCalc Irrigation Planning User Manual. NETAFIM Corporation.

Mahrous, A., Hanafy, M. Bakeer, G. A. and Bazaraa. A. S. (2008). Computer program for predicting emission uniformity of odd-shaped subunits in drip irrigation system. Misr Journal of Agricultural Engineering, 25(4): 1240-1255.

Narayanan, R., Steele, D. and Scherer, T. (2002). Computer model to optimize aboveground drip irrigation systems for small areas. Applied Engineering in Agriculture, 18, No. 4, 459-469.

Nina, P., Olga, N. Kazandjiev, V. and Lubomirova. M. C. (2012). A computer program for drip irrigation system design for small plots. Journal of Theoretical and Applied Mechanics, Sofia, 42(4): 3-18.

Pannunzio, A., M. Román, J. Brenner, and A. Wölfle. (2004b). Economic overview of drip and microirrigation systems in humid regions. p. 52. Proceedings of the VII World Citriculture Congress, Agadir, Marruecos. International Society of Citriculture (ISC), Riverside, California, USA.

Philipova, N., Nicheva, O., Kazandjiev, V. and Chilikova-Lubomirova, M. (2012). A computer program for drip irrigation system design for small plots. Journal of Theoretical and Applied Mechanics, Sofia, vol. 42, No. 4, pp. 3-18.

Rossman, L.A. (2000). Epanet 2 User's Manual; US EPA: Cincinnati, OH, USA.

Sharaf, G. A., and Hassan. A. (2006). Design of small holdings irregular shape micro irrigation unit. In the 14th. Annual Conference of the Misr Society of Agriculture Engineering. Egypt, 22 November.

Sharu, E.H., and Razak, Ms. Ab. (2020). Hydraulic performance and modelling of pressurized drip irrigation system. Water, 12, 2295; doi:10.3390/w12082295. 
Zella, L., Kettab, A. and Chasseriaux, G. (2006). Design of a micro-irrigation system based on the control volume method. Biotechnology, Agronomy, Society and Environment, 10(3): 163-171.

\section{Online irrigation software sites:}

- AFTFathom. Available online: https://www.aft.com/products/aft-software-overview.

- AquaFlow. Available online: https://www.toro.com/en/agriculture/growerconnection/design-aides/designsoftware

- DIDAS. Available online: https://app.agri.gov.il/didas/.

- DOMIS. Available online: http://domis.iari.res.in/pages/dripd.php.

- HidrauliCAD. Available online: http://hydraulicad.com/

- HydroCalc. Available online: http://www.netafim.com/hydrocalc-software-1

- Infoworks. Available online: https://www.innovyze.com/en-us/products/infoworks-wspro.

- IRRICAD. Available online: https://www.irricad.com/.

- IrriExpress. Available online: https://www.irriexpress.com/pages/about-us.

- IrriLab. Available online: https://www.facebook.com/irrilab/

- IrriPro. Available online: https://www.irriworks.com/homepage/15-design.

- WaterCAD. Available online: https://www.bentley.com/en/products/productline/hydraulics-and-hydrology-software/watercad.

- WaterGEMS. Available online: https://www.bentley.com/en/products/productline/hydraulics-and-hydrology-software/watergems. 


\section{تطبيق برنامج الهيدروكلك لاختيار التصميم الأمثل لنظام الري بالتنقيط}

\section{وليد محمد بسيوني درويش'، محمد أحمد الحويطى و محمد صبري البلكيمى"}

' أستاذ الهندسة الزر اعية المساعد ـ معهد الدراسات والبحوث البيئية ـ جامعة مدينة السادات ـ المنوفية ـ مصر.

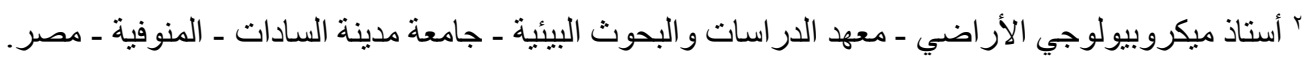
r طالب دراسات عليا بمعهد الدر اسات و البحوث البيئية ـ جامعة مدينة السادات ـ المنوفية ـ مصر.

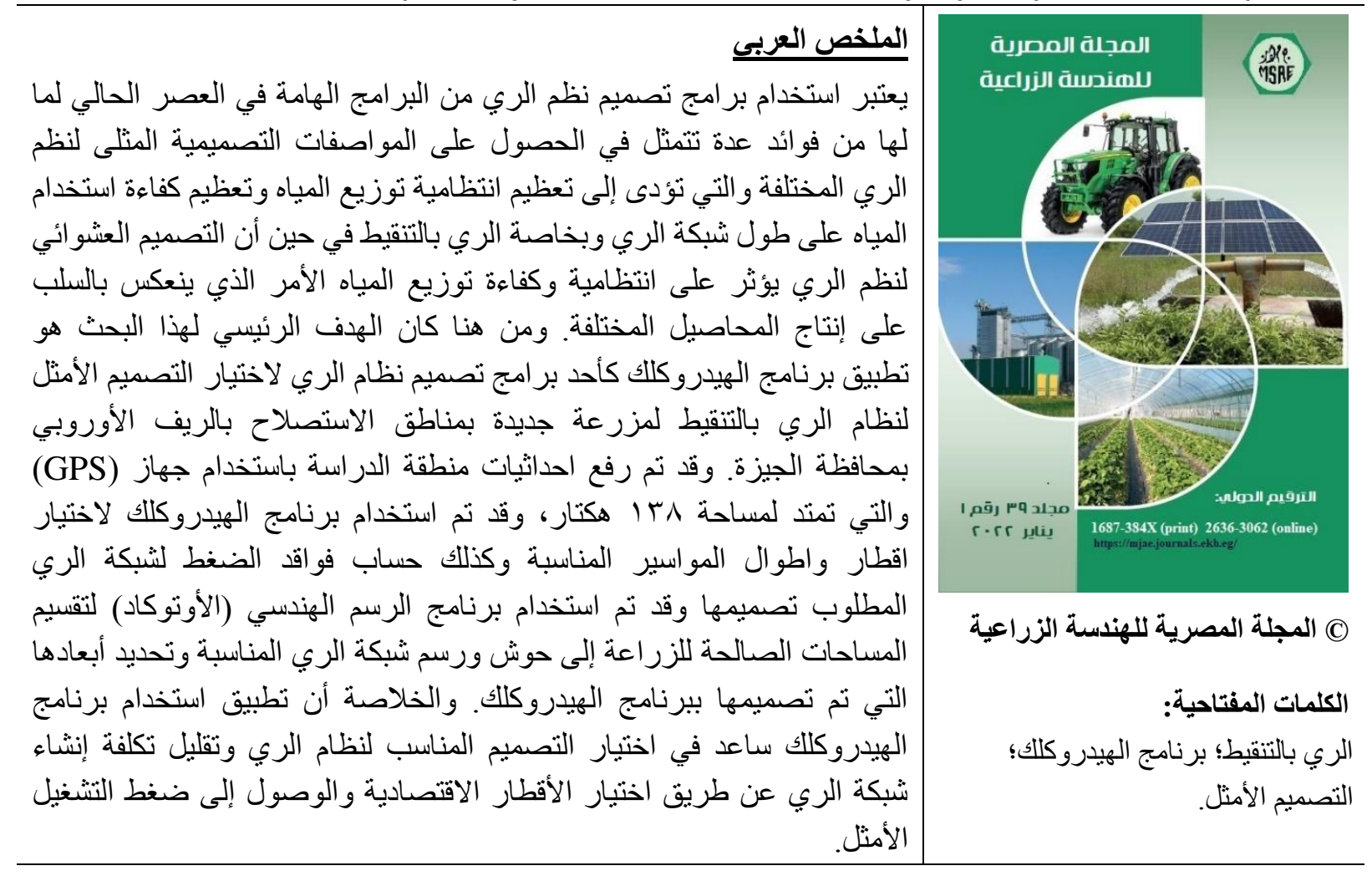

